\title{
A Novel Method for the Synthesis of Binary Molten Salt Nanofluids Adding SiO2 Nanoparticles
}

\section{Nano Express}

Keywords:

Posted Date: November 5th, 2020

DOI: https://doi.org/10.21203/rs.3.rs-97853/v2

License: (c) (i) This work is licensed under a Creative Commons Attribution 4.0 International License. Read Full License 


\section{Abstract}

The authors have requested that this preprint be withdrawn due to erroneous posting.

\section{Full Text}

The authors have withdrawn this preprint from Research Square. 